\title{
Enhanced Quaternary Exhumation in the Central Three Rivers Region, Southeastern Tibet
}

\author{
Xiaoming Shen ${ }^{1 *}$, Yuntao Tian ${ }^{2}$, Ying Wang ${ }^{3}$, Lin Wu ${ }^{4}$, Yingying Jia ${ }^{1}$, Xiudang Tang ${ }^{1}$, \\ Haijia Lei ${ }^{1}$, Xiaoping Yuan ${ }^{5}$, Yukui Ge ${ }^{3}$ and Jing Liu-Zeng ${ }^{6}$
}

\begin{abstract}
${ }^{1}$ National Institute of Natural Hazards, Ministry of Emergency Management of China, Beijing, China, ${ }^{2}$ Guangdong Provincial Key Laboratory of Geodynamics and Geohazards, School of Earth Sciences and Engineering, Sun Yat-sen University, Guangzhou, China, ${ }^{3}$ State Key Laboratory of Earthquake Dynamics, Institute of Geology, China Earthquake Administration, Beiiing, China, ${ }^{4}$ State Key Laboratory of Lithospheric Evolution, Institute of Geology and Geophysics, Chinese Academy of Sciences, Bejing, China, ${ }^{5}$ School of Earth Sciences, China University of Geosciences, Wuhan, China, ${ }^{6}$ Institute of Surface Earth System Science, Tianjin University, Tianjin, China
\end{abstract}

OPEN ACCESS

Edited by: Junsheng Nie,

Lanzhou University, China

Reviewed by:

Guangwei Li,

Nanjing University, China Jingen Dai,

China University of Geosciences,

China

${ }^{*}$ Correspondence: Xiaoming Shen xiaoming_shen@163.com

Specialty section: This article was submitted to Structural Geology and Tectonics,

a section of the journal

Frontiers in Earth Science

Received: 14 July 2021 Accepted: 19 August 2021 Published: 03 September 2021

Citation:

Shen $X$, Tian $Y$, Wang $Y$, Wu L, Jia $Y$,

Tang $X$, Lei $H$, Yuan $X, G e Y$ and

Liu-Zeng J (2021) Enhanced

Quaternary Exhumation in the Central

Three Rivers Region,

Southeastern Tibet.

Front. Earth Sci. 9:741491.

doi: 10.3389/feart.2021.741491
The roles of tectonics and climate in the global increased erosion rates during the Quaternary have been the subject of active debate. The Three Rivers Region, strongly influenced by continental convergence between India and Eurasia and change in Asian monsoon climate, is an ideal place to study the interactions between tectonics and surface processes. Here we report new apatite (U-Th)/He data from an elevation transect that reveal a phase of rapid exhumation since $\sim 2.6 \mathrm{Ma}$ in the Dulong batholith in the central Three Rivers Region, southeastern Tibetan Plateau. Based on stream profile analysis and compiled thermochronological data in the region, we demonstrate that the tectonic uplift caused by the high-strain at the corner of Indian-Eurasia convergence is responsible for the enhanced exhumation in the central Three Rivers Region in the Quaternary. Our new results highlight that the continuous plate convergence towards the plateau interior has dominated the uplift and deformation in the southeastern Tibet in the Quaternary.

Keywords: southeastern Tibet, thermochronology, stream profile analysis, quaternary, tectonic uplift

\section{INTRODUCTION}

The Earth's surface was shaped through interaction between erosion, tectonics and climate (Molnar and England, 1990; Raymo and Ruddiman, 1992) and this coupling has implications for the influence of silicate weathering and organic-carbon burial on climate and for the landscape evolution (Berner et al., 1983; France-Lanord and Derry, 1997; Kump et al., 2000). In particular, the roles of tectonics and climate in the global increased erosion rates during the Quaternary have been the subject of active debate (Zhang et al., 2001; Herman et al., 2013; Schildgen et al., 2018). A key area for understanding these processes is the Three Rivers Region, in the southeastern Tibet, where three large rivers (the Salween, Mekong, and Yangtze) run closely in parallel to form deep gorges that connect the high-elevation plateau surface to the surrounding lowlands (Figure 1). The central Three Rivers Region, at the corner of Indian-Eurasia convergence, exhibits high-strain state, high relief, rapid exhumation, and active tectonics (Henck et al., 2011; Yang et al., 2016). Meanwhile, this region is influenced by Asian Monsoon precipitation and glaciation (Fu et al., 2013) (Figure 2). These unique features make the Three Rivers Region an ideal area for investigating the interactions between tectonics and surface processes (Liu-Zeng et al., 2009). 


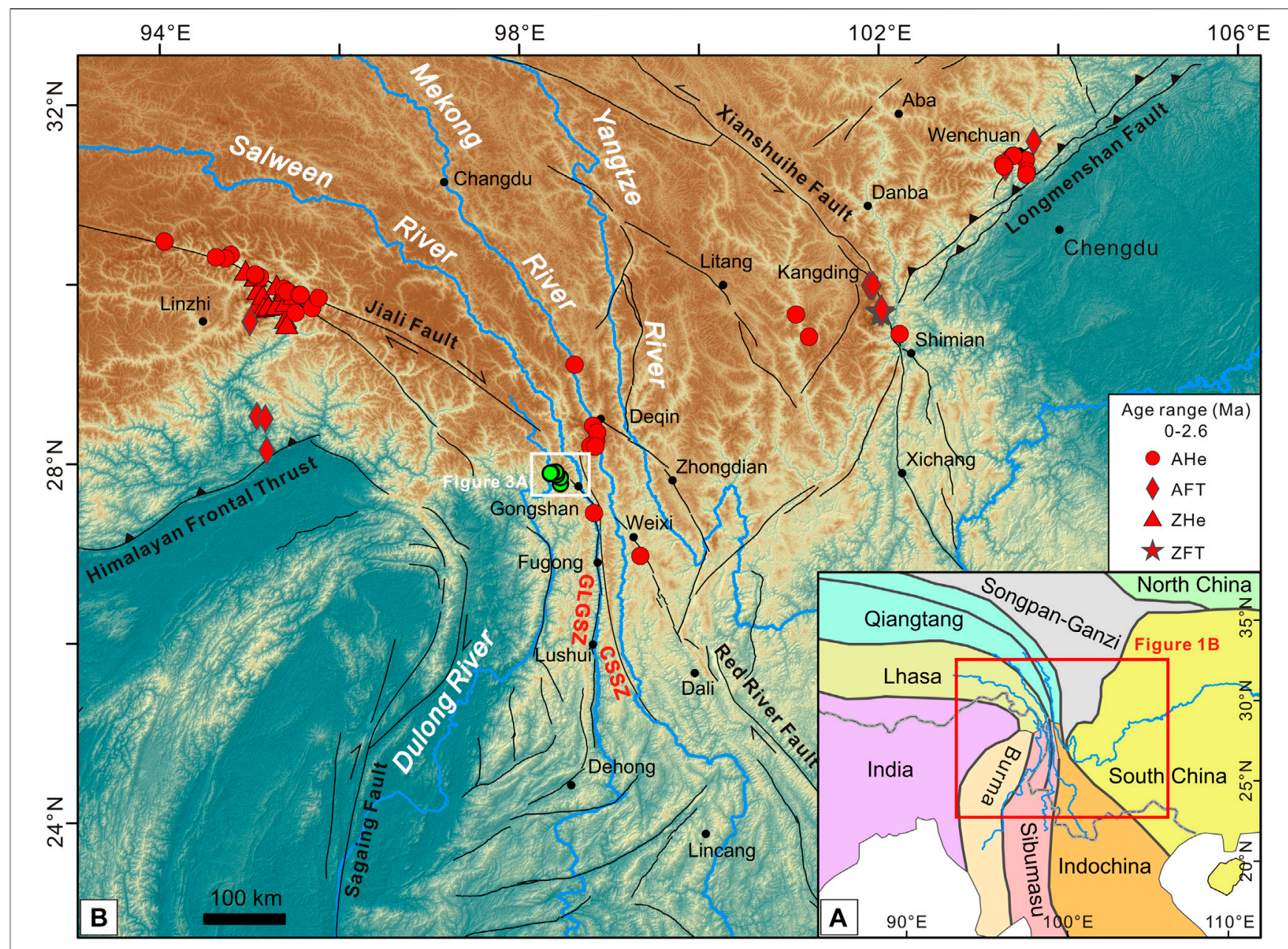

FIGURE 1 | Tectonics and regional topography of the Three Rivers Region and surrounding areas. (A) Tectonic framework of the Three Rivers Region showing the major continental blocks and suture zones. Modified from Deng et al. (2014). (B) Digital elevation model (DEM) of the topography and active faults in the Three Rivers Region, showing the study area (white rectangle) and sample locations in this study (green circles). DEM data is based on 90 m Shuttle Radar Topography Mission (SRTM). Previous thermochronological ages ( $\leq 2.6 \mathrm{Ma}$ ) marked by red are also shown (Xu and Kamp, 2000; Godard et al., 2009; Ouimet et al., 2010; Wilson and Fowler, 2011; Wang et al., 2012; Zeitler et al., 2014; Tu et al., 2015; Yang et al., 2016; Tan et al., 2017; Zhang et al., 2017; Yang et al., 2018; Shen et al., 2019; Replumaz et al., 2020; Yang et al., 2021). GLGSZ, Gaoligong shear zone; CSSZ, Chongshan shear zone.

A number of studies using thermochronometers and cosmogenic nuclides have revealed that there were multiple phases of rapid exhumation since the late Mesozoic in the Three Rivers Region (Shen et al., 2016; Yang et al., 2016; LiuZeng et al., 2018; Nie et al., 2018; Ge et al., 2020; Replumaz et al., 2020). It is worth noting that sparse (U-Th)/He ages in the Quaternary have appeared in the existing data along the valley bottom of the Salween and Mekong (Yang et al., 2016; Replumaz et al., 2020) (Figure 1B). It is unclear whether the Quaternary phase of rock exhumation is widespread in the Three Rivers Region or only locally affected, and what are the relative roles of tectonics and climate in driving enhanced exhumation. Thus, high resolution low-temperature thermochronological data are needed to reconstruct the exhumation history of this region, which will help us to decipher the mechanisms responsible for landscape evolution and plateau growth and, more generally, climate change.
In this study, we report 34 apatite (U-Th)/He (AHe) age data from six granite samples along an altitude transect that spans $1,760 \mathrm{~m}$ of relief in the Mesozoic Dulong batholith in the gorge of the Dulong River, central Three Rivers Region (Figure 3). We also compiled the available low-temperature thermochronological data in the southeastern Tibetan Plateau. Combined with stream profile analysis, our results indicate that rock uplift caused by high-strain at the corner of indenting Indian plate is responsible for the enhanced Quaternary exhumation in the central Three Rivers Region.

\section{TOPOGRAPHIC AND GEOLOGICAL SETTING}

In the Three Rivers Region, three of the largest Asian rivers traverse the southeast margin of the Tibetan Plateau, flowing 


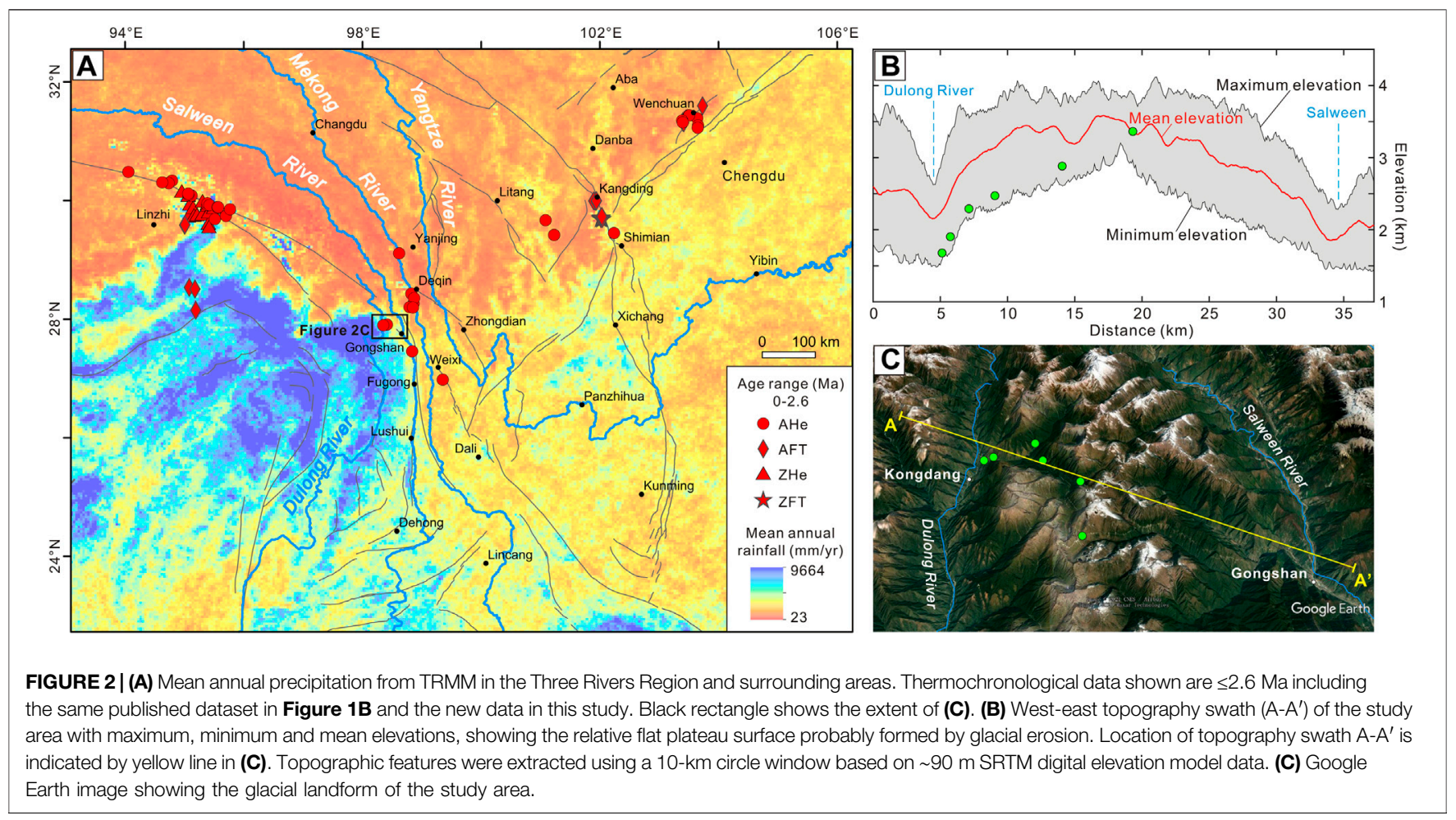

roughly parallel to each other for hundreds of kilometers and carving gorges up to $3 \mathrm{~km}$ deep. In the central Three Rivers Region, near the Gongshan, the three rivers are tightly spaced with the closest distance $<70 \mathrm{~km}$. Although low-relief and highelevation landscapes are well preserved in most regions of the southeastern Tibetan Plateau, they are absent in the central Three Rivers Region (Clark et al., 2006). Moreover, large-scale knickzones, defined by very high steepness along the longitudinal river profiles of the Salween and Mekong also occur in the central Three Rivers Region (Yang et al., 2016).

The Three Rivers Region lies adjacent to the eastern Himalayan syntaxis in the west and the South China block and Songpan-Ganzi terrane in the east (Figure 1A). During the Cenozoic, the Three Rivers Region has been subjected to oblique collision between India and Eurasia, and experienced large-scale shortening, transpressional deformation, strike-slip faulting, tectonic extrusion, and reorientation (Tapponnier et al., 2001; Ding and Zhong, 2013; Deng et al., 2014). Quaternary tectonic activity in the region is mainly strike-slip in the north and transtensional in the south (Tapponnier et al., 2001; Liu-Zeng et al., 2018). Three large-scale shear zones, from west to east, the Gaoligong, the Chongshan and the AilaoshanRed River shear zones separate the Three Rivers Region into NSoriented narrow lithospheric fragments (Deng et al., 2014). The Gaoligong and Chongshan shear zones are gradually merged northward and become tectonically amalgamated from Fugong to Gongshan area (Huang et al., 2015) (Figure 1B). These two shear zones might have initiated in the early Oligocene and the main phase of shearing occurred during 19-11 Ma (Wang et al., 2006; Zhang et al., 2012). The Ailaoshan-Red River shear zone extends from the Three Rivers Region to the South China Sea. During Miocene-Pliocene, this shear zone switched from left-lateral slip to right-lateral slip (Schoenbohm et al., 2006; Leloup et al., 2007).

Two dextral strike-slip faults, the Gaoligong fault and the Dulongjiang fault, define the eastern and western boundary of the Dulong batholith, respectively (Figure 3A). Limited studies show that the Dulongiiang fault extends north into Tibet and south into Myanmar. Field investigation in the shear zone found hornblende granulites in the Kongdang area and plagioclase amphibolite in the western Bapo area and its further south, indicating that the fault zone had reached amphibolite metamorphic facies. The tensile lineation of the minerals indicates compressive shearing during ductile strike-slip deformation. In addition, there are normal faults along the main fault zone and tributaries of the Dulong River, showing extension deformation (Lei et al., 2006). Dulong batholith is nearly parallel to the strike-slip structure and mainly composed of granodiorite and monzonitic granite. Zircon $\mathrm{U}-\mathrm{Pb}$ dating of Dulong granitoids indicated that they were formed in multiple phases during the Jurassic to Cretaceous (172-71 Ma) (Yan et al., 2002).

\section{PREVIOUS THERMOCHRONOLOGICAL STUDIES IN SOUTHEAST TIBET}

Previous thermochronological studies reported in southeast Tibet generally show two phases of rapid exhumation in the Oligocene $(\sim 30-20 \mathrm{Ma})$ and since late Miocene $(\sim 10-0 \mathrm{Ma})$, but exhibit diachroneity depending on the locality (Wang et al., 2012; Shen et al., 2016; Zhang et al., 2016). The late Miocene rapid exhumation 


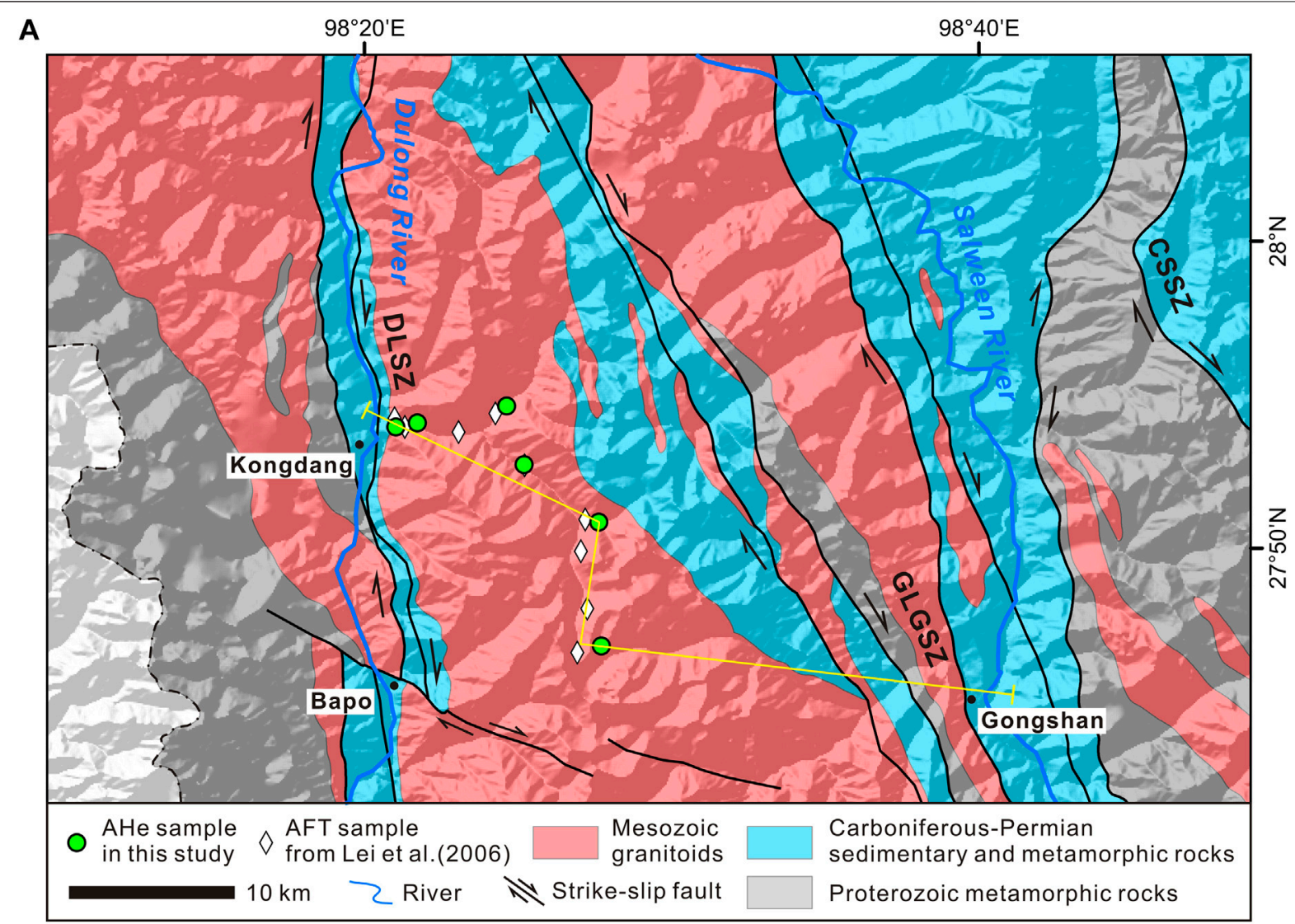

B

Dulong River (Kongdang village)

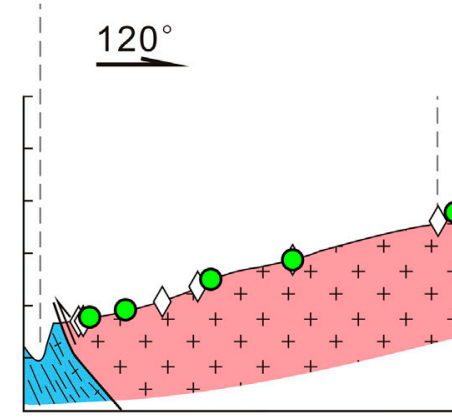

Heipushan
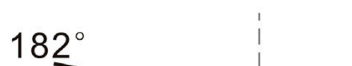

Salween
(Gongshan county)

Elevation ( $m$ )

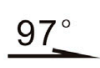

4000

$7^{4000}$

3000

2000

1000

FIGURE 3 | Simplified geological map superimposed on shaded relief (A) and a geological cross section (B) of the Dulong area. Locations of sample collected for this study and from Lei et al. (2006) are shown. Location of the geological cross section is indicated by yellow line in (A).

was suggested to reflect the regional-scale plateau uplift, intensified monsoon precipitation or fault related movement (Clark et al., 2005; Nie et al., 2018; Wang et al., 2018; Shen et al., 2019). Recently, the Quaternary increased exhumation in the region was documented by thermochronometric and cosmogenic nuclide data. In the eastern Himalayan syntaxis, enhanced Quaternary exhumation was revealed by multidisciplinary approaches (Yang et al., 2021) and the mechanism of the exhumation was proposed to relate positive feedback effect between surface processes and tectonic uplift (Zeitler et al., 2014), tectonic uplift (Wang et al.,
2014) and/or river capture events (Govin et al., 2020; Yang et al., 2021). In the central Longmen Shan, the fast Quaternary exhumation was suggested to be induced by the thrust faulting (Shen et al., 2019). In the upstream of the Dadu River from Shimian County, the rapid exhumation at $\sim 2 \mathrm{Ma}$ has been interpreted as a response to the Dadu-Anning capture (Yang et al., 2020). In the catchment of the Anninghe River, detrital apatite fission track (AFT) thermochronology recorded a phase of regional exhumation during Pleistocene which also explained by drainage network reorganization (Wang et al., 2021). 


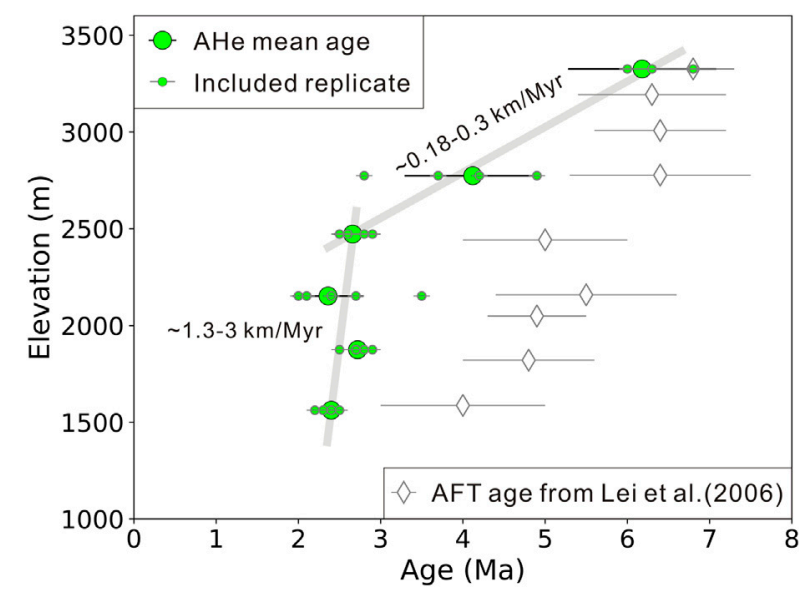

FIGURE 4 | Age-elevation relationship for the Dulong transect. Filled small circles denote grain replicates included in the mean age determination.

\section{SAMPLING AND METHOD}

\section{Sampling}

To constrain the exhumation of the Three Rivers Region, especially the section of the knickzone, sampling from a vertical transect was performed from the western margin of the central Three Rivers Region (Figures 1B, 3). Six rock samples were collected from Mesozoic granitic intrusions from the near peak of the Heipushan to the deeply incised valley bottom of the Dulong River (Kongdang Village) (Figure 3). Sample's elevations range from 3,326 to $1,562 \mathrm{~m}$, forming a vertical profile spanning $\sim 1,760 \mathrm{~m}$ relief over a lateral extent of $\sim 18 \mathrm{~km}$ (Figure $3 \mathrm{~B}$ ). The intrusions, where the samples were collected, are undeformed Mesozoic plutons with intrusive contact, in which no faulting has been observed during field investigations. Previous AFT (closure temperature, $\sim 110 \pm 20^{\circ} \mathrm{C}$; Reiners and Brandon, 2006) ages reported by Lei et al. (2006) for the same transect (Figure 3) are between 4 and $6.8 \mathrm{Ma}$ (Figure 4). To gain more detailed information for the cooling history since the Pliocene and new insights into surface processes, we report new AHe (closure temperature, $\sim 60 \pm 20^{\circ} \mathrm{C}$; Farley et al., 1996) data for the Dulong batholith.

\section{Analytical Method}

Apatite (U-Th)/He analyses for the Dulong transect were conducted at the National Institute of Natural Hazards, Ministry of Emergency Management of China (NINHMEMC). Apatite concentrates were extracted using standard crushing, sieving, electromagnetic, and heavy liquid mineral separation techniques. Apatite grains with euhedral morphology and no visible inclusions were selected under a microscope and only grains $>70 \mu \mathrm{m}$ in both length and width were considered suitable for $(\mathrm{U}-\mathrm{Th}) / \mathrm{He}$ dating. Grain dimensions were measured from digital photographs for the calculation of the equivalent spherical grain radius and the a-ejection correction factor. Each grain was then wrapped in a $1 \mathrm{~mm} \times 1 \mathrm{~mm}$ platinum capsule and loaded into the laser chamber. Each grain was thermally outgassed under vacuum at $\sim 900^{\circ} \mathrm{C}$ for $5 \mathrm{~min}$, using a diode laser (970 $\mathrm{nm}$ wavelength) with $8 \mathrm{~A}$ current. Then, spiked with ${ }^{3} \mathrm{He}$, gas volumes were determined using a PrismaPLus QME 220 quadrupole mass analyzer at NINH-MEMC. We checked that gas released during replicate heating yielded approximately the same as hot blanks to ensure total extraction for each grain. After degassing, molar abundances of $U$ and $T h$ were determined by isotope dilution using a mixed ${ }^{235} \mathrm{U}_{-}{ }^{230} \mathrm{Th}$ spike. U-Th analyses were carried out on an inductively coupled plasma quadrupole massspectrometer at NINH-MEMC. The age calculation was processed by applying the a-ejection correction factor $\left(\mathrm{F}_{\mathrm{T}}\right)$ (Farley et al., 1996) to each crystal to derive a corrected (U-Th)/He age (Table 1). The age error was derived from the analytical uncertainties in $U$ and $T h$ measurements, and the variance of the single grain ages. Six fragments of Durango apatite were run as reference standards together with and identically to our samples to verify analytical accuracy. A weighted mean average age of $31.7 \pm 0.5 \mathrm{Ma}$ (Table 1) was obtained for these fragments, which is in consistent with the nominal age of the Durango apatite (McDowell et al., 2005).

\section{Thermal History Modeling}

To investigate the thermal evolution of the Dulong vertical transect, we modeled the thermal history using the program QTQt, which has been developed to invert thermochronological ages for multiple samples with a known altitudinal relationship implementing a Markov chain Monte Carlo method (Gallagher, 2012) Figure 5. The modeling approach employs an alpha-damage-dependent kinetic model of helium diffusion in apatite (Flowers et al., 2009) and a multikinetic AFT annealing model (Ketcham et al., 2007). The AHe data in this study and AFT data from Lei et al. (2006) are modeled jointly. The input parameters used to model the thermal history for individual samples are as follows: (1) present-day mean surface temperature of $10 \pm 10^{\circ} \mathrm{C}$; (2) the prior for the paleotemperature offsets, or temperature difference between the uppermost and lowermost samples in a vertical profile, were defined as $\sim 53 \pm 53^{\circ} \mathrm{C}$ equivalent to temperature gradient prior of $30 \pm 30^{\circ} \mathrm{C} / \mathrm{km}$ (Clark et al., 2005) and the temperature offsets were also allowed to vary over time; (3) an initial time-temperature constraint is set at $100-200^{\circ} \mathrm{C}$ at a time span slightly older than the oldest AFT age. These prior settings were always included with a large uncertainty so as to give the modeling enough freedom to search for a wide range of data-constrained thermal histories. The final thermal history models were sampled 400,000 iterations: 200,000 used to stabilize or burnin the inversion, and the second 200,000 used to form the posterior ensemble (Gallagher, 2012). Exploratory runs using larger numbers did not appreciably change model outcomes.

\section{River Profile Analysis}

Bedrock river profiles are often described using the stream power incision model (Whipple and Tucker, 1999), which expresses the erosion rate in terms of channel slope and drainage area 
TABLE 1 | Single-grain apatite (U-Th)/He results from Dulong batholith, southeast Tibet.

\begin{tabular}{|c|c|c|c|c|c|c|c|c|c|c|c|c|}
\hline Sample no & $\begin{array}{l}\text { GPS location } \\
\text { and elevation }\end{array}$ & ${ }^{4} \mathrm{He}(\mathrm{mol})$ & ${ }^{238} \mathrm{U}$ (mol) & ${ }^{232} \mathrm{Th}$ (mol) & $\begin{array}{l}\text { Raw age } \\
\text { (Ma) }\end{array}$ & $\begin{array}{l}\text { Error } \\
( \pm 1 \sigma)\end{array}$ & $\mathrm{Rs}(\mu \mathrm{m})$ & $\mathbf{F}_{\mathbf{T}}$ & $\begin{array}{l}\text { Corrected } \\
\text { age (Ma) }\end{array}$ & $\begin{array}{l}\text { Error } \\
( \pm 1 \sigma)\end{array}$ & $\begin{array}{c}\text { Mean } \\
\text { age }( \pm 1 \sigma) \\
(\mathrm{Ma})\end{array}$ & eU (ppm) \\
\hline G18-1-1 & $98.4622^{\circ} \mathrm{E}$ & $3.72 \mathrm{E}-15$ & 5.99E-13 & $1.82 \mathrm{E}-13$ & 4.5 & 0.1 & 59.9 & 0.752 & 6.0 & 0.1 & $6.18 \pm 0.90$ & 38.7 \\
\hline G18-1-2 & $27.7801^{\circ} \mathrm{N}$ & $2.32 \mathrm{E}-15$ & $1.47 \mathrm{E}-13$ & $4.38 \mathrm{E}-14$ & 11.5 & 0.4 & 55.7 & 0.739 & 15.5 & 0.5 & & 11.4 \\
\hline G18-1-3 & $3,326 \mathrm{~m}$ & $6.52 \mathrm{E}-15$ & $3.00 \mathrm{E}-13$ & $3.26 \mathrm{E}-13$ & 13.4 & 0.3 & 51.4 & 0.724 & 18.6 & 0.4 & & 32.3 \\
\hline G18-1-4 & & 5.32E-15 & $7.65 \mathrm{E}-13$ & $3.41 \mathrm{E}-13$ & 4.9 & 0.1 & 53.3 & 0.721 & 6.8 & 0.2 & & 73.6 \\
\hline G18-1-5 & & 1.83E-15 & $2.91 \mathrm{E}-13$ & $1.36 \mathrm{E}-13$ & 4.4 & 0.1 & 48.5 & 0.696 & 6.3 & 0.2 & & 36.8 \\
\hline G17-4-1 & $98.4609^{\circ} \mathrm{E}$ & $2.93 \mathrm{E}-15$ & 3.97E-13 & $1.60 \mathrm{E}-12$ & 3.0 & 0.1 & 64.9 & 0.705 & 4.2 & 0.1 & $4.12 \pm 0.83$ & 36.3 \\
\hline G17-4-2 & $27.8474^{\circ} \mathrm{N}$ & 4.73E-15 & $6.90 \mathrm{E}-13$ & 2.60E-12 & 2.8 & 0.1 & 83.1 & 0.770 & 3.7 & 0.1 & & 26.2 \\
\hline G17-4-3 & $2,774 \mathrm{~m}$ & $4.51 \mathrm{E}-15$ & $5.54 \mathrm{E}-13$ & $1.87 \mathrm{E}-12$ & 3.6 & 0.1 & 69.6 & 0.727 & 4.9 & 0.1 & & 31.7 \\
\hline G17-4-4 & & 1.19E-15 & $1.60 \mathrm{E}-13$ & 6.36E-13 & 3.0 & 0.1 & 54.9 & 0.712 & 4.2 & 0.1 & & 18.9 \\
\hline G17-4-5 & & 8.19E-16 & $2.00 \mathrm{E}-13$ & $5.12 \mathrm{E}-13$ & 2.0 & 0.1 & 54.4 & 0.713 & 2.8 & 0.1 & & 19.7 \\
\hline G17-4-6 & & $4.55 \mathrm{E}-15$ & $5.02 \mathrm{E}-13$ & $2.10 \mathrm{E}-12$ & 3.6 & 0.1 & 57.7 & 0.726 & 4.9 & 0.1 & & 51.9 \\
\hline G17-5-1 & $98.4204^{\circ} \mathrm{E}$ & 4.99E-15 & $9.10 \mathrm{E}-13$ & $4.41 \mathrm{E}-12$ & 2.0 & 0.0 & 80.0 & 0.760 & 2.6 & 0.0 & $2.66 \pm 0.23$ & 39.6 \\
\hline G17-5-2 & $27.8786^{\circ} \mathrm{N}$ & 1.66E-15 & $3.62 \mathrm{E}-13$ & $1.41 \mathrm{E}-12$ & 1.9 & 0.0 & 73.3 & 0.739 & 2.5 & 0.1 & & 19.7 \\
\hline G17-5-3 & 2,472 m & $2.52 E-15$ & 4.66E-13 & $2.08 \mathrm{E}-12$ & 2.1 & 0.0 & 71.2 & 0.731 & 2.8 & 0.0 & & 28.9 \\
\hline G17-5-4 & & $2.50 \mathrm{E}-15$ & $5.09 \mathrm{E}-13$ & $2.37 \mathrm{E}-12$ & 1.8 & 0.0 & 72.5 & 0.735 & 2.5 & 0.0 & & 33.2 \\
\hline G17-5-5 & & $9.55 \mathrm{E}-16$ & $1.84 \mathrm{E}-13$ & 8.08E-13 & 2.0 & 0.0 & 61.6 & 0.689 & 2.9 & 0.1 & & 20.0 \\
\hline G17-6-1 & $98.4109^{\circ} \mathrm{E}$ & $1.24 \mathrm{E}-15$ & 4.09E-13 & 1.43E-12 & 1.3 & 0.0 & 54.7 & 0.652 & 2.0 & 0.1 & $2.36 \pm 0.43$ & 55.2 \\
\hline G17-6-2 & $27.9103^{\circ} \mathrm{N}$ & 4.26E-15 & $7.29 \mathrm{E}-13$ & $2.78 \mathrm{E}-12$ & 2.4 & 0.1 & 63.2 & 0.698 & 3.5 & 0.1 & & 67.7 \\
\hline G17-6-3 & $2,152 \mathrm{~m}$ & 1.73E-15 & $5.57 \mathrm{E}-13$ & $1.85 \mathrm{E}-12$ & 1.4 & 0.0 & 53.3 & 0.644 & 2.1 & 0.0 & & 78.0 \\
\hline G17-6-4 & & $2.68 \mathrm{E}-15$ & 8.32E-13 & $2.88 \mathrm{E}-12$ & 1.4 & 0.0 & 56.6 & 0.664 & 2.1 & 0.0 & & 91.3 \\
\hline G17-6-5 & & $1.31 \mathrm{E}-15$ & 3.95E-13 & $1.18 \mathrm{E}-12$ & 1.5 & 0.0 & 50.4 & 0.624 & 2.4 & 0.0 & & 66.2 \\
\hline G17-6-6 & & 1.03E-15 & 3.34E-13 & 1.16E-12 & 1.3 & 0.0 & 45.7 & 0.656 & 2.0 & 0.0 & & 61.6 \\
\hline G17-6-7 & & $2.11 \mathrm{E}-15$ & $4.44 \mathrm{E}-13$ & $1.75 \mathrm{E}-12$ & 1.9 & 0.0 & 57.5 & 0.725 & 2.7 & 0.1 & & 47.5 \\
\hline G17-6-8 & & 1.13E-15 & $3.81 \mathrm{E}-13$ & 8.37E-13 & 1.5 & 0.0 & 55.6 & 0.721 & 2.1 & 0.1 & & 36.7 \\
\hline G17-7-1 & $98.3625^{\circ} \mathrm{E}$ & $3.90 \mathrm{E}-15$ & $8.29 \mathrm{E}-13$ & $3.10 \mathrm{E}-12$ & 2.0 & 0.0 & 63.1 & 0.698 & 2.8 & 0.0 & $2.72 \pm 0.11$ & 71.8 \\
\hline G17-7-2 & $27.9012^{\circ} \mathrm{N}$ & 4.84E-15 & $9.52 \mathrm{E}-13$ & $3.72 \mathrm{E}-12$ & 2.1 & 0.0 & 67.3 & 0.716 & 2.9 & 0.0 & & 74.1 \\
\hline G17-7-3 & $1,875 \mathrm{~m}$ & $2.15 \mathrm{E}-15$ & $5.55 \mathrm{E}-13$ & $1.81 \mathrm{E}-12$ & 1.7 & 0.0 & 53.8 & 0.647 & 2.7 & 0.0 & & 79.4 \\
\hline G17-7-4 & & 2.79E-15 & 7.03E-13 & 2.63E-12 & 1.7 & 0.0 & 49.8 & 0.617 & 2.7 & 0.0 & & 131.9 \\
\hline G17-7-5 & & $2.58 \mathrm{E}-15$ & $6.55 \mathrm{E}-13$ & 1.95E-12 & 1.8 & 0.0 & 57.7 & 0.672 & 2.7 & 0.0 & & 67.2 \\
\hline G17-7-6 & & $2.08 \mathrm{E}-15$ & $5.73 \mathrm{E}-13$ & 1.89E-12 & 1.6 & 0.0 & 51.4 & 0.630 & 2.5 & 0.0 & & 93.9 \\
\hline G17-8-1 & $98.3508^{\circ} \mathrm{E}$ & 5.54E-15 & $1.74 \mathrm{E}-12$ & $1.94 \mathrm{E}-12$ & 2.0 & 0.0 & 119.2 & 0.845 & 2.3 & 0.0 & $2.40 \pm 0.16$ & 16.1 \\
\hline G17-8-2 & $27.8989^{\circ} \mathrm{N}$ & $2.28 \mathrm{E}-15$ & $6.71 \mathrm{E}-13$ & $9.72 \mathrm{E}-13$ & 2.0 & 0.0 & 96.8 & 0.808 & 2.4 & 0.0 & & 13.4 \\
\hline G17-8-3 & $1,562 \mathrm{~m}$ & $2.97 \mathrm{E}-15$ & $8.63 \mathrm{E}-13$ & $1.07 \mathrm{E}-12$ & 2.1 & 0.1 & 101.1 & 0.817 & 2.5 & 0.1 & & 13.0 \\
\hline G17-8-4 & & $3.42 \mathrm{E}-15$ & $1.04 \mathrm{E}-12$ & 1.43E-12 & 1.9 & 0.0 & 95.8 & 0.806 & 2.4 & 0.0 & & 18.6 \\
\hline DUR076 & & $7.51 \mathrm{E}-14$ & $3.41 \mathrm{E}-13$ & 6.99E-12 & 29.8 & 0.5 & & & & & $31.74 \pm 0.48$ & \\
\hline DUR077 & & $8.85 \mathrm{E}-14$ & $3.71 \mathrm{E}-13$ & 7.70E-12 & 32.0 & 0.6 & & & & & & \\
\hline DUR078 & & 7.32E-14 & $3.14 \mathrm{E}-13$ & $6.43 \mathrm{E}-12$ & 31.6 & 0.6 & & & & & & \\
\hline DUR079 & & $5.69 \mathrm{E}-14$ & $2.55 \mathrm{E}-13$ & 4.99E-12 & 31.4 & 0.5 & & & & & & \\
\hline DUR080 & & $6.98 \mathrm{E}-14$ & $2.96 \mathrm{E}-13$ & $6.08 \mathrm{E}-12$ & 31.9 & 0.6 & & & & & & \\
\hline DUR081 & & 7.76E-14 & $3.28 \mathrm{E}-13$ & $6.75 \mathrm{E}-12$ & 31.9 & 0.5 & & & & & & \\
\hline
\end{tabular}

Rs: Radius of a sphere with the equivalent surface area-to-volume ratio as cylindrical crystals (Meesters and Dunai, 2002).

Ft: $\alpha$-ejection correction factor (Farley et al., 1996).

Mean age: Weighted means calculated using IsoplotR Nermeesch, 2018). Evidently older age outliers are highlighted in bold and are excluded from calculation of the weighted mean age. eU: Effective uranium content, $[\mathrm{eU}]=[\mathrm{U}]+0.235 \times[\mathrm{Th}]$ (Flowers et al., 2009).

$$
\frac{\partial z(x, t)}{\partial \mathrm{t}}=\mathrm{U}(\mathrm{x}, \mathrm{t})-\mathrm{K}(\mathrm{x}) \mathrm{A}(\mathrm{x}, \mathrm{t})^{\mathrm{m}} S^{\mathrm{n}}
$$

where $\left(\frac{\partial z(x, t)}{\partial t}\right)$ is the change in elevation of the channel bed with respect to time, $\mathrm{U}$ is rock uplift rate relative to the base level, $\mathrm{K}$ is rock erodibility, $\mathrm{A}$ is drainage area, $\mathrm{S}$ is channel slope, $\mathrm{m}$ and $\mathrm{n}$ are constants. Under the assumption of a topographic steady state $\left(\frac{\partial z(x, t)}{\partial t}=0\right)$ and $U$ and $K$ are spatially and temporally uniform, the equilibrium slope is then a function of

$$
S=\left(\frac{U}{K}\right)^{\frac{1}{n}} A^{-\frac{m}{n}}
$$

where $\frac{m}{n}$ is the concavity of the equilibrium profile and $\left(\frac{U}{K}\right)^{\frac{1}{n}}$ is the channel steepness which can be determined by scaling the slope and area relationship.

Deriving the channel slope data directly from the digital elevation model (DEM) can be problematic due to the noise of the DEM data. To avoid the scatter of noise during the estimation of slope, we used an alternative method (Perron and Royden, 
2013) for the equilibrium river profiles by substituting the channel slope with elevation, which leads to

$$
\mathrm{z}(\mathrm{x})=\mathrm{z}\left(\mathrm{x}_{\mathrm{b}}\right)+\left(\frac{\mathrm{U}}{\mathrm{KA}_{0}^{\mathrm{m}}}\right)^{\frac{1}{\mathrm{n}}} \chi
$$

and

$$
\chi=\int_{\mathrm{x}_{\mathrm{b}}}^{\mathrm{x}}\left(\frac{\mathrm{A}_{0}}{\mathrm{~A}\left(\mathrm{x}^{\prime}\right)}\right)^{\frac{\mathrm{m}}{\mathrm{n}}} \mathrm{dx^{ \prime }}
$$

where $\mathrm{x}_{\mathrm{b}}$ is the reference of local base level, and $\mathrm{A}_{0}$ is an arbitrary scaling factor. Then channel steepness $\mathrm{K}_{\mathrm{sn}}$ is the slope of the $\chi$-elevation plot

$$
K_{s \mathrm{n}}=\left(\frac{\mathrm{U}}{\mathrm{KA}_{0}^{\mathrm{m}}}\right)^{\frac{1}{\mathrm{n}}}
$$

which is proportional to the rock uplift rate.

We used the SRTM DEM, which has a resolution of $\sim 90 \mathrm{~m}$, to extract the longitudinal profiles and steepness index of the Dulong and Salween rivers (Figure 6). A threshold drainage area of $5 \mathrm{~km}^{2}$ was used to exclude regions that are potentially dominated by debris flows or hillslope processes. We selected a concavity, $\mathrm{m} / \mathrm{n}$, of 0.45 and a scaling area, $A_{0}$, of $1 \mathrm{~m}^{2}$ (Wobus et al., 2006). The channel steepness was then estimated from the slope of the $\chi$-plot with the linear regression method by using a $\chi$ interval of 1 .

\section{RESULTS}

\section{New Apatite (U-Th)/He Data}

Four to eight single-grain AHe age analyses were performed for each of the six Dulong samples, as summarized in Table 1. The samples yield mostly consistent $\mathrm{AHe}$ ages except the uppermost sample (G18-1) has two abnormally old ages. The two AHe outliers of sample G18-1 do not show clear relationships with eU and grain size (Table 1), indicating radiation damage and grain size variation do not appear to be controlling the distribution of ages (Gautheron et al., 2012). U-zoning in the core leads to overestimate of the alpha-ejection correction, but cannot explain the abnormally old ages in our study, because even the uncorrected ages (11.5 and $13.4 \mathrm{Ma}$ ) of the two grains are older than the AFT age $(6.8 \pm 0.5 \mathrm{Ma})$ at the same elevation. Additional sources of ${ }^{4} \mathrm{He}$ other than the analyzed apatite, such as U-rich mineral inclusions in apatite, U-rich neighbouring minerals (Spiegel et al., 2009) may be possible explanations for the outliners. Excluding outliers, all remaining AHe data show a strong positive relationship with elevation (Figure 4). The ageelevation relationship has an inflection point at the elevation of $\sim 2,500 \mathrm{~m}$, and the AHe ages below this point are generally less than $3 \mathrm{Ma}$, while the $\mathrm{AHe}$ age above are significantly older (3-7 Ma). Excluding outliers, the calculated weighted mean AHe ages range from $6.18 \pm 0.9$ to $2.36 \pm 0.43 \mathrm{Ma}$ and show a positive correlation with elevation. The regression of the ageelevation relationship suggests a significant increase in erosion rate from $\sim 0.18-0.3 \mathrm{~km} /$ Myr to $\sim 1.3-3.0 \mathrm{~km} / \mathrm{Myr}$ after $\sim 2.6 \mathrm{Ma}$ (see below for the timing from the thermal history modeling).

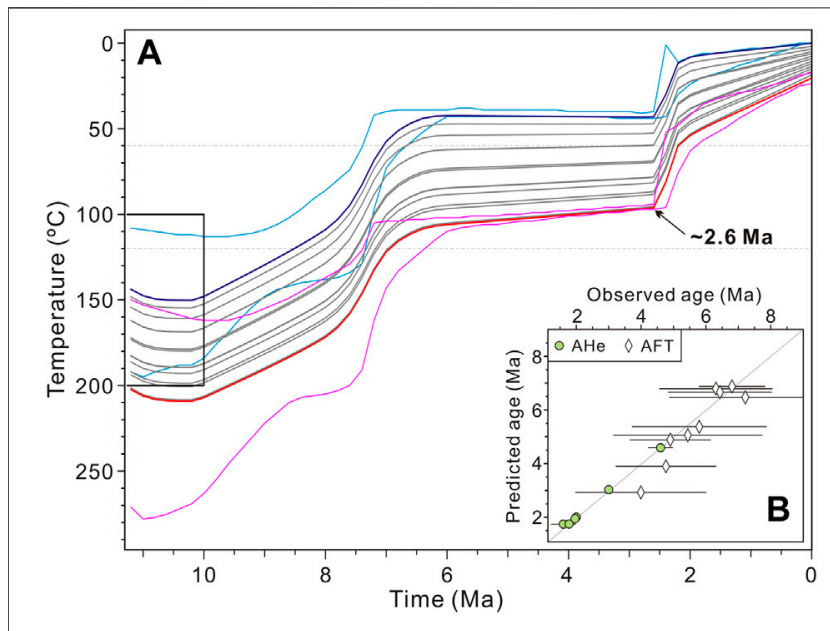

FIGURE 5 | Thermal modeling results (A) for the Dulong transect using QTQt (Gallagher, 2012) and comparison of observed and predicted thermochronological data (B). The thermal history of the uppermost sample is plotted in thick blue, the lowermost sample in thick red, and the intermediate samples in dashed grey. For the uppermost thermal history, the thin blue lines depict the 95\% confidence intervals, reflecting the uncertainty in the inferred thermal history alone. For the lowermost thermal history, the thin red lines show the 95\% confidence intervals, reflecting combined uncertainties in the inferred thermal history and temperature offset. For comparison of observed and predicted data, the AHe ages are uncorrected ones.

\section{Thermal History}

The modeling results show a thermal history with two phases of rapid cooling since the late Miocene (Figure 5A). The first episode commenced at $\sim 7-8 \mathrm{Ma}$; all the samples passed through the AFT partial annealing zone (PAZ) rapidly and some upper samples might have reached the AHe partial retention zone (PRZ) during this cooling event. This phase of fast cooling also revealed by the overlap of the AHe and AFT ages $(\sim 6-7 \mathrm{Ma})$ in the uppermost elevation (Figure 4). However, the current available data cannot provide a precise constraint on the timing of onset. The duration of this episode of rapid cooling, the induced mechanism and the potential links to tectonics or climate change need further work that are well beyond the scope of this study. After the first phase of fast cooling, a period of slow cooling or isothermal holding lasted for $~ 5 \mathrm{Myr}$; then the cooling rate increased at $\sim 2.6 \mathrm{Ma}$, and all the samples exhumed to the near Earth's surface (Figure 5A). Such a thermal history is generally consistent with our thermochronological observations (Figure 5B). Note that the AHe observations are very well fitted by the modeled values, supporting the validity of the Quaternary enhanced cooling and exhumation (Figure 5A). In summary, the inverse modeling results from the vertical transect suggest that it experienced two episodes of rapid cooling commenced before Pliocene and at the beginning of the Quaternary, which are in accordance with the ageelevation profile (Figure 4). In the sections below, we focus on the Quaternary enhanced cooling and expand its implications to regional exhumation and tectonics. 


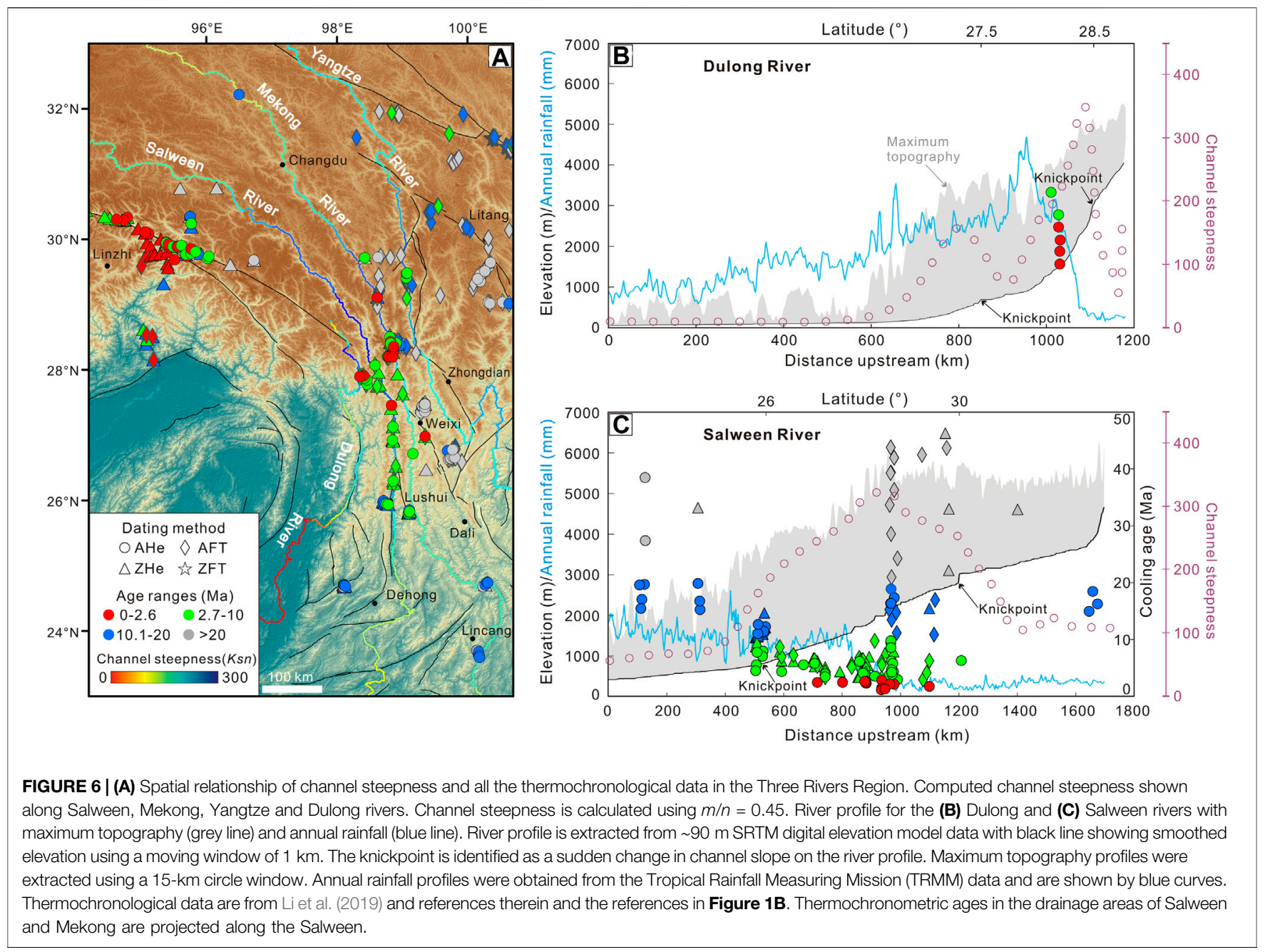

\section{DISCUSSION}

\section{Enhanced Quaternary Exhumation in the Central Three Rivers Region}

Our new AHe data and thermal modeling suggest increased exhumation rates in the upper reach of the Dulong River, central Three Rivers Region, at the beginning of the Quaternary ( 2.6 Ma) (Figure 5). Although our data cannot provide detailed information for the exhumation processes after 2.4 Ma (Figure 4), the mean exhumation rate of $\sim 0.83 \mathrm{~mm} /$ year since $\sim 2.4 \mathrm{Ma}$ can be estimated given the $\sim 2 \mathrm{~km}$ magnitude of erosion derived from the closure temperature of AHe $\left(\sim 60 \pm 20^{\circ} \mathrm{C}\right.$; Farley et al., 1996$)$ and the recommended geothermal gradient $\left(\sim 30^{\circ} \mathrm{C} / \mathrm{km}\right.$; Clark et al., 2005) in the region. Thus, we conclude that the study area should have experienced faster exhumation during the Quaternary than before (Figures 4, 5). This is similar with previous findings from thermochronological studies at about the same latitude in the gorges of the Salween and Mekong (Figure 1B). Pre-existing thermochronological data from the valley bottoms of the Salween and Mekong have suggested enhanced exhumation $(>0.75 \mathrm{~mm} /$ year) near $28^{\circ} \mathrm{N}$ in the past $2 \mathrm{Myr}$ (Yang et al., 2016). A recently reported set of AHe and AFT data from Kawagebo massif have also revealed rapid Quaternary exhumation $(>1 \mathrm{~mm} /$ year) at the valley bottom of the Mekong (Replumaz et al., 2020). Our results suggest that this increase in exhumation rate has also occurred in the upper Dulong River, the western margin of the central Three Rivers Region. Together with previous studies, we infer that an enhanced Quaternary exhumation with significant magnitude may exist in the central Three Rivers Region. This conclusion is supported by the increase in sedimentary flux to the marginal sea basins in the past 2 Myr (Métivier et al., 1999; Clift, 2006).

\section{Tectonic Control on Rapid Quaternary Exhumation in the Three Rivers Region}

It is worth noting that all the young thermochronological ages younger than $2.6 \mathrm{Ma}$ in the Three Rivers Region are located between 26 and $30^{\circ} \mathrm{N}$ (Figure 6A), implying that the central part of the Three Rivers Region may have experienced fast erosion during the Quaternary. The locus of rapid erosion was focused at the same area in different river gorges may suggest that the same mechanism may underline this phase of fast exhumation in the central Three Rivers Region. As mentioned above, the Quaternary 
enhanced exhumation could be induced by tectonic uplift, climate change, river reorganization or fault activity. Based on several lines of evidence, the rapid Quaternary exhumation in the central Three Rivers Region was most likely controlled by localized tectonic uplift. First, the locus of rapid erosion coincides with the conspicuous large-scale knickzone in the Three Rivers Region (Figure 6). In this region, the Three Rivers and the Dulong River are most closely spaced, have the highest steepness index in river long profiles, coinciding with the steepest reach in plateau edge as suggested by the maximum elevation envelop (Figures 6B,C). The pattern of the knickzones, with high steepness values limited to the knickzone region and similar lower values above and below the knickzones (Figures 6B,C), identifies they as "vertical-step" knickpoints (Kirby and Whipple, 2012), suggesting that they are related to spatially focused rock uplift given that there is no obvious variation in lithology associated with the knickzones (Replumaz et al., 2020). Second, in the central Three Rivers Region, the low-relief and high-elevation landscapes are absent (Clark et al., 2006) due to the intense dissection and high relief, which may be caused by the local uplift. Third, short-term (millennial) erosion pattern in the Three Rivers Region revealed by detrital cosmogenic nuclide was used to infer that tectonics is the primary control and the eastwest enhanced erosion gradient mirrors a gradient in rock uplift rates (Henck et al., 2011). Fourth, structural and kinematic analyses reveal that the amalgamation area of the Gaoligong and Chongshan shear zones, from Fugong to Gongshan area, is just located at the neck of the large-scale boudin structure and experienced strongly partitioned dextral transpression and consequent uplift at the corner of the eastern Himalayan syntaxis (Huang et al., 2015). Finally, in nearby region, enhanced rock uplift since ca. $2.5-2 \mathrm{Ma}$ in the eastern Himalayan syntaxis has been inferred from the existence of Quaternary thick alluvium sediments above the Yarlung Tsangpo gorge (Wang et al., 2014) and multiple thermochronometries and geomorphology analysis (King et al., 2016; Salvi et al., 2017; Yang et al., 2021). It is likely that the Quaternary enhanced exhumation in the Three Rivers Region is synchronous with the eastern Himalayan syntaxis, and a response to the continuous indentation of the northeast corner of the Indian plate.

\section{The Role of Climate on Erosion}

It is significant that the ages we obtained for the initiation of rapid exhumation in the central Three Rivers Region ( 2.6 Ma) closely approximate the estimated timing of global cooling (Herman et al., 2013). U-shaped valleys are widely distributed above $\sim 3,000 \mathrm{~m}$ in the Dulong area (Figure 2C), indicating the imprint of glacial erosion. The past extent of glaciers in the southeast Tibet, reconstructed based on glacial landforms and sediments, indicates that this was one of the most extensively glaciated area of the Tibetan Plateau during the Quaternary (Li, 1996; Fu et al., 2013). However, only a few areas exhibit rapid Quaternary exhumation implied by low-temperature thermochronology in the vast region of the southeast Tibet (Figure 1B), suggesting the glacial erosion was not the main force for the fast exhumation in the Three Rivers Region.

The Three Rivers Region is strongly influenced by the Asian monsoon precipitation (An et al., 2001) (Figure 2A). The youngest ages in the Three Rivers Region are in the area where the precipitation rate decreases abruptly (Figure 6B,C and $\mathbf{2 A}$ ). Along the Salween, the modern rainfall increases steadily from the immediately south of the edge-plateau to the lowland while erosion rates decrease (Figure 6C). Thus, if during the Quaternary the climatic gradient was similar to the modern one, the exhumation pattern is unlikely related to the precipitation.

Drainage area loss or gain will decrease or increase the erosion rate near the capture point based on the stream power law (Whipple and Tucker, 1999). Potential capture of the formerly northwest-to-southeast-flowing paleo-Yarlung Tsangpo-Dulong River by the Brahmaputra River was proposed as the drainage reorganization event in the region (Clark et al., 2004), although the timing of this process is still unclear. However, if this capture event took place in the headwater of the Dulong River, the loss of the drainage area would result in the decreased erosion rate in the downstream of the capture point. This case is not supported by the observation of our study. Our results cannot preclude the possibility of the rapid exhumation induced by river capture in the downstream of the knickzone of the Dulong River, but we argue that even though the river capture occurred in the Quaternary and resulted in the consequent rapid exhumation, it was possible triggered by the enhanced rock uplift.

In summary, although climatic factors or river capture may play somewhat roles on the enhanced Quaternary exhumation in the central Three Rivers Region, the localized tectonic uplift may have exerted firstorder control on this exhumation, similar to the eastern Himalayan syntaxis, the central Longmen Shan and the Gongga Shan where the tectonics activity was regarded as active during the recent past.

\section{Implications for the Plateau Growth}

The geodynamics of the formation of the southeastern Tibetan Plateau is hotly debated. Various models have been proposed to explain the plateau growth and the formation of the unique landscape in this region. They include: indentation and progressive crustal thickening (England and McKenzie, 1982), tectonic extrusion (Tapponnier et al., 2001), lower crustal channel flow (Clark and Royden, 2000) or whole crustal flow (Copley and McKenzie, 2007) driven by the topographic difference between the plateau and its surroundings. Although the timing of each model exerted is still controversy, all existing models have in common that the southeastern Tibetan Plateau must have grown outwards with respect to its interior. This outward expansion of the plateau is also thought to be responsible for the propagation of topography and thus the focus of erosion. However, our new results and the available datasets indicate that the locus of rapid erosion in the recent geological past was confined to the central part of Three Rivers Region rather than the plateau margin (Figure 6A), in contrast to previous plateau expansion models. Our results cannot provide constrains on the topographic evolution or surface uplift during the Quaternary. Nevertheless, significant regional rock uplift in the high-strain zone probably caused by the expansion of the eastern Himalayan syntaxis is required to explain the previous and our new thermochronological data in the Three Rivers Region. 


\section{CONCLUSION}

We present new apatite (U-Th)/He data from an elevation transect of the deep gorge of the Dulong River. Our new results and thermal modelling reveal a phase of rapid exhumation since $\sim 2.6 \mathrm{Ma}$ in the central Three Rivers Region. Combined with the river profile analysis and the exiting thermochronological data in the region, we propose that the localized rock uplift may have exerted first-order control on this exhumation in the Quaternary rather than the climate change. Our results also imply that the locus of fast exhumation in the past $2.6 \mathrm{Myr}$ in the Three Rivers Region is only restricted in the central part of this region, challenging the proposed models for plateau outward growth of its margins.

\section{DATA AVAILABILITY STATEMENT}

The original contributions presented in the study are included in the article/supplementary material, further inquiries can be directed to the corresponding author.

\section{REFERENCES}

Berner, R. A., Lasaga, A. C., and Garrels, R. M. (1983). The Carbonate-Silicate Geochemical Cycle and its Effect on Atmospheric Carbon Dioxide over the Past 100 Million Years. Am. J. Sci. 283, 641-683. doi:10.2475/ajs.283.7.641

Clark, M. K., House, M. A., Royden, L. H., Whipple, K. X., Burchfiel, B. C., Zhang, X., et al. (2005). Late Cenozoic Uplift of southeastern Tibet. Geol. 33, 525-528. doi:10.1130/g21265.1

Clark, M. K., Royden, L. H., Whipple, K. X., Burchfiel, B. C., Zhang, X., and Tang, W. (2006). Use of a Regional, Relict Landscape to Measure Vertical Deformation of the Eastern Tibetan Plateau. J. Geophys. Res. 111, F03002. doi:10.1029/2005jf000294

Clark, M. K., Schoenbohm, L. M., Royden, L. H., Whipple, K. X., Burchfiel, B. C., Zhang, X., et al. (2004). Surface Uplift, Tectonics, and Erosion of Eastern Tibet from Large-Scale Drainage Patterns. Tectonics 23, 1006-1029. doi:10.1029/ 2002 tc001402

Clift, P. D. (2006). Controls on the Erosion of Cenozoic Asia and the Flux of Clastic Sediment to the Ocean. Earth Planet. Sci. Lett. 241, 571-580. doi:10.1016/ j.epsl.2005.11.028

Copley, A., and McKenzie, D. (2007). Models of Crustal Flow in the India-Asia Collision Zone. Geophys. J. Int. 169, 683-698. doi:10.1111/j.1365246x.2007.03343.x

Deng, J., Wang, Q., Li, G., and Santosh, M. (2014). Cenozoic TectonoMagmatic and Metallogenic Processes in the Sanjiang Region, Southwestern China. Earth-Science Rev. 138, 268-299. doi:10.1016/ j.earscirev.2014.05.015

Ding, L., and Zhong, D. (2013). The Tectonic Evolution of the Eastern Himalya Syntaxis since the Collision of the Indian and Eurasian Plates. Chin. J. Geology 48, 317-333. doi:10.3969/j.issn.0563-5020.2013.02.001

England, P., and McKenzie, D. (1982). A Thin Viscous Sheet Model for continental Deformation. Geophys. J. Int. 70, 295-321. doi:10.1111/j.1365246x.1982.tb04969.x

Farley, K. A., Wolf, R. A., and Silver, L. T. (1996). The Effects of Long AlphaStopping Distances on (U-Th)/He Ages. Geochimica et Cosmochimica Acta 60, 4223-4229. doi:10.1016/s0016-7037(96)00193-7

Flowers, R. M., Ketcham, R. A., Shuster, D. L., and Farley, K. A. (2009). Apatite (U-Th)/He Thermochronometry Using a Radiation Damage Accumulation and Annealing Model. Geochimica et Cosmochimica Acta 73, 2347-2365. doi:10.1016/j.gca.2009.01.015

\section{AUTHOR CONTRIBUTIONS}

XS conceived the idea and did the field work. XS, YT, YW, LW, YJ, XT, and HL prepared the samples and conducted the experiments. XS, YT, JL, and YJ discussed. XS and YT contributed to the modeling. XS interpreted the data and wrote the paper. XY, YG, and JL-Z improved the figures. All authors contributed to the revision of the text.

\section{FUNDING}

This work was supported by the National Natural Science Foundation of China (42073052, 42030305).

\section{ACKNOWLEDGMENTS}

We thank Desmond Patterson for technical support to the Alphachron at NINH-MEMC, Jinyu Zhang for help in river profile analysis. Constructive reviews by the two reviewers as well as editorial work by Junsheng Nie are gratefully appreciated.

France-Lanord, C., and Derry, L. A. (1997). Organic Carbon Burial Forcing of the Carbon Cycle from Himalayan Erosion. Nature 390, 65-67. doi:10.1038/36324 Fu, P., Harbor, J. M., Stroeven, A. P., Hättestrand, C., Heyman, J., and Zhou, L. (2013). Glacial Geomorphology and Paleoglaciation Patterns in Shaluli Shan, the southeastern Tibetan Plateau - Evidence for Polythermal Ice Cap Glaciation. Geomorphology 182, 66-78. doi:10.1016/j.geomorph.2012.10.030

Gallagher, K. (2012). Transdimensional Inverse thermal History Modeling for Quantitative Thermochronology. J. Geophys. Res. Solid Earth 117, B02408. doi:10.1029/2011jb008825

Gautheron, C., Tassan-Got, L., Ketcham, R. A., and Dobson, K. J. (2012). Accounting for Long Alpha-Particle Stopping Distances in (U-Th-Sm)/He Geochronology: 3D Modeling of Diffusion, Zoning, Implantation, and Abrasion. Geochimica et Cosmochimica Acta 96, 44-56. doi:10.1016/ j.gca.2012.08.016

Ge, Y., Liu-Zeng, J., Zhang, J., Wang, W., Tian, Y., Fox, M., et al. (2020). Spatiotemporal Variation in Rock Exhumation Linked to Large-Scale Shear Zones in the southeastern Tibetan Plateau. Sci. China Earth Sci. 63, 512-532. doi:10.1007/s11430-019-9567-y

Godard, V., Pik, R., Lave, J., Cattin, R., Tibari, B., de Sigoyer, J., et al. (2009). Late Cenozoic Evolution of the central Longmen Shan, Eastern Tibet: Insight from (U-Th)/He Thermochronometry. Tectonics 28, TC5009. doi:10.1029/ 2008 tc002407

Govin, G., van der Beek, P., Najman, Y., Millar, I., Gemignani, L., Huyghe, P., et al. (2020). Early Onset and Late Acceleration of Rapid Exhumation in the Namche Barwa Syntaxis, Eastern Himalaya. Geology 48, 1139-1143. doi:10.1130/ g47720.1

Henck, A. C., Huntington, K. W., Stone, J. O., Montgomery, D. R., and Hallet, B. (2011). Spatial Controls on Erosion in the Three Rivers Region, southeastern Tibet and Southwestern China. Earth Planet. Sci. Lett. 303, 71-83. doi:10.1016/ j.epsl.2010.12.038

Herman, F., Seward, D., Valla, P. G., Carter, A., Kohn, B., Willett, S. D., et al. (2013). Worldwide Acceleration of Mountain Erosion under a Cooling Climate. Nature 504, 423-426. doi:10.1038/nature12877

Huang, X., Xu, Z., Li, H., and Cai, Z. (2015). Tectonic Amalgamation of the Gaoligong Shear Zone and Lancangjiang Shear Zone, Southeast of Eastern Himalayan Syntaxis. J. Asian Earth Sci. 106, 64-78. doi:10.1016/ j.jseaes.2014.12.018

Ketcham, R. A., Carter, A., Donelick, R. A., Barbarand, J., and Hurford, A. J. (2007), Improved Modeling of Fission-Track Annealing in Apatite. Am. Mineral. 92, 799-810. doi:10.2138/am.2007.2281 
King, G. E., Herman, F., and Guralnik, B. (2016). Northward Migration of the Eastern Himalayan Syntaxis Revealed by OSL Thermochronometry. Science 353, 800-804. doi:10.1126/science.aaf2637

Kirby, E., and Whipple, K. X. (2012). Expression of Active Tectonics in Erosional Landscapes. J. Struct. Geology 44, 54-75. doi:10.1016/j.jsg.2012.07.009

Kristen Clark, M., and Handy Royden, L. (2000). Topographic Ooze: Building the Eastern Margin of Tibet by Lower Crustal Flow. Geology 28, 703-706. doi:10.1130/0091-7613(2000)028<0703:tobtem >2.3.co;2

Kump, L. R., Brantley, S. L., and Arthur, M. A. (2000). Chemical Weathering, Atmospheric CO2, and Climate. Annu. Rev. Earth Planet. Sci. 28, 611-667. doi:10.1146/annurev.earth.28.1.611

Lei, Y., Ji, J., Gong, D., Zhong, D., Wang, X., Zhang, J., et al. (2006). Thermal and Denudational History of Granitoid Batholith Recorded by Apatite Fission Track in the Dulong River Region in Northwestern Yunnan, since Late Miocene. Acta Petrologica Sinica 22, 938-948.

Leloup, P. H., Tapponnier, P., Lacassin, R., and Searle, M. P. (2007). Discussion on the Role of the Red River Shear Zone, Yunnan and Vietnam, in the continental Extrusion of SE Asia Journal, Vol. 163, 2006, 1025-10361025-1036. J. Geol. Soc. 163, 1253-1260. doi:10.1144/0016-76492007-065

Li, H.-A., Dai, J.-G., Xu, S.-Y., Liu, B.-R., Han, X., Wang, Y.-N., et al. (2019). The Formation and Expansion of the Eastern Proto-Tibetan Plateau: Insights from Low-Temperature Thermochronology. J. Asian Earth Sci. 183, 103975. doi:10.1016/j.jseaes.2019.103975

Li, X. (1996). Landforms in Drung River basin. Yunnan Geogr. Environ. Res. 8, 59-72.

Liu-Zeng, J., Zeng, L. S., Ding, L., Tapponier, P., Gaudemer, Y., Li, W., et al. (2009). Tectonic Geomorphology, Active Tectonics and Lower Crustal Channel Flow Hypothesis of the southeastern Tibetan Plateau. Chin. J. Geology 44, 1227-1255. doi:10.12017/dzkx.0563-5020(2009)04-1227-29

Liu-Zeng, J., Zhang, J., McPhillips, D., Reiners, P., Wang, W., Pik, R., et al. (2018). Multiple Episodes of Fast Exhumation since Cretaceous in Southeast Tibet, Revealed by Low-Temperature Thermochronology. Earth Planet. Sci. Lett. 490, 62-76. doi:10.1016/j.epsl.2018.03.011

McDowell, F. W., McIntosh, W. C., and Farley, K. A. (2005). A Precise 40Ar-39Ar Reference Age for the Durango Apatite (U-Th)/He and Fission-Track Dating Standard. Chem. Geology 214, 249-263. doi:10.1016/j.chemgeo.2004.10.002

Meesters, A. G. C. A., and Dunai, T. J. (2002). Solving the Production-Diffusion Equation for Finite Diffusion Domains of Various Shapes. Chem. Geology 186, 347-363. doi:10.1016/s0009-2541(02)00073-6

Métivier, F., Gaudemer, Y., Tapponnier, P., and Klein, M. (1999). Mass Accumulation Rates in Asia during the Cenozoic. Geophys. J. Int. 137, 280-318.

Molnar, P., and England, P. (1990). Late Cenozoic Uplift of Mountain Ranges and Global Climate Change: Chicken or Egg? Nature 346, 29-34. doi:10.1038/ 346029a0

Nie, J., Ruetenik, G., Gallagher, K., Hoke, G., Garzione, C. N., Wang, W., et al. (2018). Rapid Incision of the Mekong River in the Middle Miocene Linked to Monsoonal Precipitation. Nat. Geosci. 11, 944-948. doi:10.1038/s41561-0180244-z

Ouimet, W., Whipple, K., Royden, L., Reiners, P., Hodges, K., and Pringle, M. (2010). Regional Incision of the Eastern Margin of the Tibetan Plateau. Lithosphere 2, 50-63. doi:10.1130/157.1

Perron, J. T., and Royden, L. (2013). An Integral Approach to Bedrock River Profile Analysis. Earth Surf. Process. Landforms 38, 570-576. doi:10.1002/esp.3302

Raymo, M. E., and Ruddiman, W. F. (1992). Tectonic Forcing of Late Cenozoic Climate. Nature 359, 117-122. doi:10.1038/359117a0

Reiners, P. W., and Brandon, M. T. (2006). Using Thermochronology to Understand Orogenic Erosion. Annu. Rev. Earth Planet. Sci. 34, 419-466. doi:10.1146/annurev.earth.34.031405.125202

Replumaz, A., San José, M., Margirier, A., van der Beek, P., Gautheron, C., Leloup, P. H., et al. (2020). Tectonic Control on Rapid Late-Miocene - Quaternary Incision of the Mekong River Knickzone, Southeast Tibetan Plateau. Tectonics 39, e2019TC005782. doi:10.1029/2019tc005782

Salvi, D., Mathew, G., and Kohn, B. (2017). Rapid Exhumation of the Upper Siang Valley, Arunachal Himalaya since the Pliocene. Geomorphology 284, 238-249. doi:10.1016/j.geomorph.2016.09.032

Schildgen, T. F., van der Beek, P. A., Sinclair, H. D., and Thiede, R. C. (2018). Spatial Correlation Bias in Late-Cenozoic Erosion Histories Derived from Thermochronology. Nature 559, 89-93. doi:10.1038/s41586-018-0260-6
Schoenbohm, L. M., Burchfiel, B. C., Liangzhong, C., and Jiyun, Y. (2006). Miocene to Present Activity along the Red River Fault, China, in the Context of continental Extrusion, Upper-Crustal Rotation, and Lower-Crustal Flow. Geol. Soc. America Bull. 118, 672-688. doi:10.1130/b25816.1

Shen, X., Tian, Y., Li, D., Qin, S., Vermeesch, P., and Schwanethal, J. (2016). Oligocene-Early Miocene River Incision Near the First bend of the Yangze River: Insights from Apatite (U-Th-Sm)/He Thermochronology. Tectonophysics 687, 223-231. doi:10.1016/j.tecto.2016.08.006

Shen, X., Tian, Y., Zhang, G., Zhang, S., Carter, A., Kohn, B., et al. (2019). Late Miocene Hinterland Crustal Shortening in the Longmen Shan Thrust Belt, the Eastern Margin of the Tibetan Plateau. J. Geophys. Res. Solid Earth 124, 11972-11991. doi:10.1029/2019jb018358

Spiegel, C., Kohn, B., Belton, D., Berner, Z., and Gleadow, A. (2009). Apatite (U-Th-Sm)/He Thermochronology of Rapidly Cooled Samples: The Effect of He Implantation. Earth Planet. Sci. Lett. 285, 105-114. doi:10.1016/ j.epsl.2009.05.045

Tan, X.-B., Xu, X.-W., Lee, Y.-H., Lu, R.-Q., Liu, Y., Xu, C., et al. (2017). Late Cenozoic Thrusting of Major Faults along the central Segment of Longmen Shan, Eastern Tibet: Evidence from Low-Temperature Thermochronology. Tectonophysics 712-713, 145-155. doi:10.1016/ j.tecto.2017.05.016

Tapponnier, P., Xu, Z. Q., Roger, F., Meyer, B., Arnaud, N., Wittlinger, G., et al. (2001). Oblique Stepwise Rise and Growth of the Tibet Plateau. Science 294, 1671-1677. doi:10.1126/science.105978

Tu, J.-Y., Ji, J.-Q., Sun, D.-X., Gong, J.-F., Zhong, D.-L., and Han, B.-F. (2015). Thermal Structure, Rock Exhumation, and Glacial Erosion of the Namche Barwa Peak, Constraints from Thermochronological Data. J. Asian Earth Sci. 105, 223-233. doi:10.1016/j.jseaes.2015.03.035

Wang, E., Kirby, E., Furlong, K. P., van Soest, M., Xu, G., Shi, X., et al. (2012). Twophase Growth of High Topography in Eastern Tibet during the Cenozoic. Nat. Geosci. 5, 640-645. doi:10.1038/ngeo1538

Wang, P., Scherler, D., Liu-Zeng, J., Mey, J., Avouac, J.-P., Zhang, Y., et al. (2014). Tectonic Control of Yarlung Tsangpo Gorge Revealed by a Buried canyon in Southern Tibet. Science 346, 978-981. doi:10.1126/ science. 1259041

Wang, Y., Fan, W., Zhang, Y., Peng, T., Chen, X., and Xu, Y. (2006). Kinematics and 40Ar/39Ar Geochronology of the Gaoligong and Chongshan Shear Systems, Western Yunnan, China: Implications for Early Oligocene Tectonic Extrusion of SE Asia. Tectonophysics 418, 235-254. doi:10.1016/j.tecto.2006.02.005

Wang, Y., Liu, C., Zheng, D., Zhang, H., Yu, J., Pang, J., et al. (2021). Multistage Exhumation in the Catchment of the Anninghe River in the SE Tibetan Plateau: Insights from Both Detrital Thermochronology and Topographic Analysis. Geophys. Res. Lett. 48, e2021GL092587. doi:10.1029/2021gl092587

Wang, Y., Zhang, P., Schoenbohm, L. M., Zheng, W., Zhang, B., Zhang, J., et al. (2018). Two-Phase Exhumation along Major Shear Zones in the SE Tibetan Plateau in the Late Cenozoic. Tectonics 37, 2675-2694. doi:10.1029/ 2018tc004979

Whipple, K. X., and Tucker, G. E. (1999). Dynamics of the Stream-Power River Incision Model: Implications for Height Limits of Mountain Ranges, Landscape Response Timescales, and Research Needs. J. Geophys. Res. 104, 17661-17674. doi:10.1029/1999jb900120

Wilson, C. J. L., and Fowler, A. P. (2011). Denudational Response to Surface Uplift in East Tibet: Evidence from Apatite Fission-Track Thermochronology. Geol. Soc. America Bull. 123, 1966-1987. doi:10.1130/b30331.1

Wobus, C., Whipple, K. X., Kirby, E., Snyder, N., Johnson, J., Spyropolou, K., et al. (2006). Tectonics from Topography: Procedures, Promise, and Pitfalls. Geol. Soc. Am. Spec. Papar 398, 55-74. doi:10.1130/2006.2398(04)

$\mathrm{Xu}$, G., and Kamp, P. J. J. (2000). Tectonics and Denudation Adjacent to the Xianshuihe Fault, Eastern Tibetan Plateau: Constraints from Fission Track Thermochronology. J. Geophys. Res. 105, 19231-19251. doi:10.1029/ 2000jb900159

Yan, C., Xia, G., and Deng, R. (2002). Characteristics of Dulongjiang Granite and Magmatism in Morthwest Yunnan. Yunan Dizhi 1, 21-33. doi:10.3969/ j.issn.1004-1885.2002.01.002

Yang, R., Fellin, M. G., Herman, F., Willett, S. D., Wang, W., and Maden, C. (2016). Spatial and Temporal Pattern of Erosion in the Three Rivers Region, southeastern Tibet. Earth Planet. Sci. Lett. 433, 10-20. doi:10.1016/ j.epsl.2015.10.032 
Yang, R., Herman, F., Fellin, M. G., and Maden, C. (2018). Exhumation and Topographic Evolution of the Namche Barwa Syntaxis, Eastern Himalaya. Tectonophysics 722, 43-52. doi:10.1016/j.tecto.2017.10.026

Yang, R., Herman, F., Liu, T., Biswas, R. H., Fellin, M. G., Tian, Y., et al. (2021). Enhanced Quaternary Exhumation in the Namche Barwa Syntaxis, Eastern Himalaya. Geology 49, 958-962. doi:10.1130/g48595.1

Yang, R., Suhail, H. A., Gourbet, L., Willett, S. D., Fellin, M. G., Lin, X., et al. (2020). Early Pleistocene Drainage Pattern Changes in Eastern Tibet: Constraints from Provenance Analysis, Thermochronometry, and Numerical Modeling. Earth Planet. Sci. Lett. 531, 115955. doi:10.1016/j.epsl.2019.115955

Zeitler, P. K., Meltzer, A. S., Brown, L., Kidd, W. S. F., Lim, C., Enkelmann, E., et al. (2014). Tectonics and Topographic Evolution of Namche Barwa and the Easternmost Lhasa Block, Tibet, toward an Improved Understanding of Uplift Mechanisms and the Elevation History of the Tibetan Plateau. Geol. Soc. America 507, 23-58. doi:10.1130/ 2014.2507(02)

Zhang, B., Zhang, J., Zhong, D., Yang, L., Yue, Y., and Yan, S. (2012). Polystage Deformation of the Gaoligong Metamorphic Zone: Structures, 40Ar/39Ar Mica Ages, and Tectonic Implications. J. Struct. Geology 37, 1-18. doi:10.1016/j.jsg.2012.02.007

Zhang, H., Oskin, M. E., Liu-Zeng, J., Zhang, P., Reiners, P. W., and Xiao, P. (2016). Pulsed Exhumation of interior Eastern Tibet: Implications for Relief Generation Mechanisms and the Origin of High-Elevation Planation Surfaces. Earth Planet. Sci. Lett. 449, 176-185. doi:10.1016/j.epsl.2016.05.048

Zhang, P., Peter, M., and William, R., D. (2001). Increased Sedimentation Rates and Grain Sizes 2-4 Myr Ago Due to the Influence of Climate Change on Erosion Rates. Nature 410, 891-897. doi:10.1038/35073504
Zhang, Y.-Z., Replumaz, A., Leloup, P. H., Wang, G.-C., Bernet, M., van der Beek, P., et al. (2017). Cooling History of the Gongga Batholith: Implications for the Xianshuihe Fault and Miocene Kinematics of SE Tibet. Earth Planet. Sci. Lett. 465, 1-15. doi:10.1016/j.epsl.2017.02.025

Zhisheng, A., Kutzbach, J. E., Prell, W. L., and Porter, S. C. (2001). Evolution of Asian Monsoons and Phased Uplift of the Himalaya-Tibetan Plateau since Late Miocene Times. Nature 411, 62-66. doi:10.1038/35075035

Conflict of Interest: The authors declare that the research was conducted in the absence of any commercial or financial relationships that could be construed as a potential conflict of interest.

Publisher's Note: All claims expressed in this article are solely those of the authors and do not necessarily represent those of their affiliated organizations, or those of the publisher, the editors and the reviewers. Any product that may be evaluated in this article, or claim that may be made by its manufacturer, is not guaranteed or endorsed by the publisher.

Copyright (c) 2021 Shen, Tian, Wang, Wu, Jia, Tang, Lei, Yuan, Ge and Liu-Zeng. This is an open-access article distributed under the terms of the Creative Commons Attribution License (CC BY). The use, distribution or reproduction in other forums is permitted, provided the original author(s) and the copyright owner(s) are credited and that the original publication in this journal is cited, in accordance with accepted academic practice. No use, distribution or reproduction is permitted which does not comply with these terms. 